\title{
DIGITAL TRANSFORMATION OF URBAN GOVERNANCE IN CHINA: THE EMERGENCE AND EVOLUTION OF SMART CITIES
}

\author{
Bo Qinin, ${ }^{1 *}$ Su Qi ${ }^{2}$ \\ 'Public Policy Lab, Renmin University of China \\ 59, Zhongguancun str., Haidian District, Beijing, \\ People's Republic of China, 100872 \\ ${ }^{2}$ Renmin University of China \\ 59, Zhongguancun str., Haidian District, Beijing, \\ People's Republic of China, 100872
}

\section{Abstract}

This research article contributes to the field of digital governance as it reviews the conceptual definition and practical application of "smart cities" in the context of urban development in China. By analyzing both firsthand interview data and secondary statistical and policy reports during the period between 2009 to 2019, we contend that the emergence of smart cities in China has evolved from a disorderly process to a more standardized one. During this process, cities made efforts to use digital technology - such as $5 \mathrm{G}$, cloud computing, and the Internet of Things - in social governance, infrastructure, and industrial development. However, such rapid development also spawned a series of emerging legal issues, which had a huge impact on China's legal system. The article seeks to holistically examine the discourse surrounding the concept of a "smart city" and its practical implementation by drawing attention to its promises as well as criticisms. The article also touches upon the challenges - such as "information islands" in construction, technology, and management - that confront the emerging smart cities, and emphasizes China's need to further improve laws and regulations, build an integrated legal system, explore new regulation methods, shape a highly autonomous and refined governance order, and provide legal protection for the development of smart cities. The paper concludes by mentioning possible areas for further research to find a developmental path for "smart cities" that can realize resource integration and sharing.

\section{Keywords}

smart city, urban governance, legal system, China

Conflict of interest The authors declare no conflict of interest.

Financial disclosure The study had no sponsorship. 
For citation

Qin, B., \& Qi, S. (2021). Digital transformation of urban governance in China: The emergence and evolution of smart cities. Digital Law Journal, 2(1), 29-47. https://doi.org/10.38044/2686-9136-2021-2-1-29-47

* Corresponding author

Submitted: 19 Jan. 2021, accepted: 22 Feb. 2021, published: 31 Mar. 2021

\title{
СТАТЬИ
}

ЦИФРОВАЯ ТРАНСФОРМАЦИЯ ГОРОДСКОГО УПРАВЛЕНИЯ В КИТАЕ: ГЕНЕЗИС УМНЫХ ГОРОДОВ

\author{
Б. Цинь ${ }^{1 *}$, С. Ци² \\ 1Лаборатория публичной политики, Университет Женьминь \\ 100872, Китайская Народная Республика, Пекин, район Хайдянь, \\ ул. Чжунгуаньцунь, 59 \\ ${ }^{2}$ Университет Женьминь \\ 100872, Китайская Народная Республика, Пекин, район Хайдянь, \\ ул. Чжунгуаньцунь, 59
}

\section{Аннотация}

Статья посвящена проблеме цифрового управления в умных городах на примере Китае. Проанализировав данные опросов и статистических и политических отчетов за период между 2009 и 2019 гг., авторы пришли к выводу, что хаотичный процесс появления умных городов в Китае приобрел более стандартизованный характер. В ходе цифровой трансформации городского управления использовались такие технологий как $5 \mathrm{G}$, облачные вычисления и «интернет вещей» в социальном управлении, инфраструктуре и промышленном развитии. Тем не менее столь бурное развитие технологий породило ряд новых юридических проблем, оказавших значительное влияние на правовую систему Китая. Авторы предпринимают попытку системно осмыслить концепцию «умный город» и ее реализацию на практике путем привлечения внимания к перспективам и критике развития умных городов. Более того, в статье затрагиваются проблемы «информационных островов» в строительстве, технологиях и управлении, с которыми сталкиваются в процессе цифровой трансформации городского управления, а также подчеркивается необходимость дальнейшего совершенствования законодательства Китая, в создании интегрированной правовой системы и изучении новых методов регулирования. Особое внимание уделяется потребности сформировать автономный и усовершенствованный порядок управления и обеспечить правовую охрану развития умных городов.

\section{Ключевые слова}

умные города, городское управление, правовая система, Китай

Конфликт интересов Авторы сообщают об отсутствии конфликта интересов. 
Финансирование

Исследование не имело спонсорской поддержки.

Для цитирования

Цинь, Б., Ци, С. (2021). Цифровая трансформация городского управления в Китае: возникновение умных городов. Цифровое право, 2(1), 29-47. https://doi.org/10.38044/2686-9136-2021-2-1-29-47

* Автор, ответственный за переписку

Поступила: 19.01.2021; принята в печать: 22.02.2021; опубликована: 31.03.2021

This research article reviews the conceptual evolution and practical application of the concept of a smart city in China. This concept has become popular in cities worldwide since its first proposal. It is regarded as a strategic choice to improve the efficiency of urban governance and the quality of public services, as well as to promote urban industrial transformation and urban sustainable development (Shengzu et al., 2013). In the past few decades, China has experienced rapid development in technology, such as the Internet of Things, big data, cloud computing, and artificial intelligence; this laid the foundation for smart cities. Many cities, such as Ningbo, Nanjing, Shenzhen, Shanghai, and Guangzhou, proposed the development of a "smart city" and issued various plans and policies to promote its implementation (Shengzu \& Min, 2012). Recently, the technologies involved in developing a smart city have been widely used to support the prevention and control of the COVID-19 pandemic in China, including drug research and development, epidemiological investigation, epidemic visualization, analysis and prediction, auxiliary decision-making, intelligent architecture, online office and teaching, logistics and transportation, and so on. The benefits of smart cities have thus, to some extent, been tested in practice.

\section{The Emergence and Evolution of Smart Cities}

\section{The Developmental Background of Smart Cities}

In the 21st century, human society has significantly been transformed, with a "rural" world having turned into an "urban" one. According to the data released by the United Nations Department of Economic and Social Affairs, $55 \%$ of the world's population lived in cities in 2018, while the number is expected to reach $68 \%$ by 2050. However, this rapid urbanization has also resulted in many problems pertaining to waste disposal, air pollution, resource shortages, health, traffic congestion, insufficient infrastructure, and many more. Worldwide, as cities are looking for smarter ways of dealing with such challenges, a "smart city" has been proposed as one way of dealing with such challenges (Alawadhi et al., 2012).

A notable feature of a smart city is the use of information and communication technology (ICT) infrastructure to improve economic efficiency and promote social, cultural, and urban development. It utilizes the new technological revolution represented by ICT, the Internet of Things, and cloud computing, which enabled cities to continuously improve their ability to perceive, process, integrate, and apply data, so that they can deal with more complex problems. In 2008, International Business Machines (IBM) put forward the vision of "smart earth", hoping to use advanced ICT to build a new world operating model

Department of Economic and Social Affairs. (2019). World urbanization prospects: The 2018 revision (ST/ESA/SER.A/420). United Nations. https:// population.un.org/wup/Publications/Files/WUP2018-Report.pdf 
and to explore new driving forces for urban development after the financial crisis. In 2009, IBM officially proposed the concept of "smart city" on the basis of the notion of "smart earth". It was proposed that a smart city should be able to make full use of ICT, responding intelligently to various needs of people's livelihood, environmental protection, public security, urban services, and industrial and commercial activities; this would create a better urban life for human beings. ${ }^{2}$

Notably, the concept of a smart city has been influenced by neoliberalism, which represents economic growth and business orientation (Hollands, 2008). In the face of increasing economic competition among cities, business-oriented development strategies have been accepted and implemented by many urban governments (Caragliu et al., 2011).

\section{Conceptual Definition of a "Smart City"}

Various definitions of a smart city have been proposed in different scholarly backgrounds (Table 1). As a smart city is based on ICT: some scholars and institutions put more emphasis on the role of technology, while others regard it from a broader perspective and eventually define it as an organic interconnected system.

A narrower perspective of a smart city emphasizes the application of technology to make urban infrastructure and services more intelligent, interconnected, and efficient (Washburn et al., 2010). This kind of intelligence and efficiency requires an instrumented urban environment. With the help of various sensors, electronic devices, and applications, the operational state of key urban infrastructure can be monitored and integrated (Harrison et al., 2010) to form a self-monitoring and self-reaction mechanism of the city itself. ${ }^{3}$ Processing various data with the help of technology can optimize the function of urban infrastructure, provide more efficient services, and promote economic cooperation and innovation (Marsal-Llacuna et al., 2015). This definition of a smart city has technology at its core and is committed to creating a smart urban environment to improve the efficiency of urban operation and realize economic growth. However, less attention is paid to urban economic, cultural, and social activities as conducted by human beings, and thus it has been criticized for being too technology-oriented (Hollands, 2008).

The narrower definition of a smart city gives a technical pathway, while the broader definition provides a comprehensive vision of urban governance involving more fields. Giffinger ${ }^{4}$ offers a comprehensive definition of a smart city that includes six aspects: smart economy, smart governance, smart environment, smart people, smart mobility, and smart living. This is a more operational definition that is important in guiding the practice of a smart city. Neirotti (2014) give an even broader definition and divided smart cities into six dimensions which include natural resources and energy, transport and mobility, buildings, living, government, economy, and people.

A smart city, in a broad sense, involves many different dimensions. Nam and Pardo (2011) structured it into three dimensions: technology, people, and system, which not only includes the narrower sense of technology, but also summarizes the content of people and institution in the broad concept. A more simplified and abstract definition summarizes these dimensions into "hard field" and "soft field". The former includes energy, transport, environment, and buildings, while the latter includes

IBM. (n.d.). IBM Research - China. Retrieved January 7, 2020. https://www.research.ibm.com/labs/china/index.shtml Hall, R. E., Bowerman, B., Braverman, J., Taylor, J., Todosow, H., \& Wimmersperg, U. (2000, September 28). The vision of a smart city. Paper presented at the Proceedings of the $2^{\text {nd }}$ International Life Extension Technology Workshop, Paris, France.

Giffinger, R., Fertner, C., Kramar, H., Kalasek, R., Pichler-Milanovic, N., \& Meijers, E. (2007). Smart cities: Ranking of European medium-sized cities (Report). Vienna University of Technology. https://gretere.miigaik.ru/sites/default/files/ materials/3_00_Ranking\%20of\%20European\%20medium-sized\%20cities.pdf 
Цифровое право. Том 2, № 1, 2021, с. 29-47

Б. Цинь, С. Ци / Цифровая трансформация городского управления в Китае

\section{Table 1}

\section{Definitions of a Smart City}

\section{Definition}

The use of Smart Computing technologies to make the critical infrastructure components and services of a city (which include city administration, education, healthcare, public safety, real estate, transportation, and utilities) more intelligent, interconnected, and efficient.

A city connecting the physical infrastructure, ICT infrastructure, social infrastructure, and business infrastructure to leverage the collective intelligence of the city.

A city that monitors and integrates the conditions of all its critical infrastructures, including roads, bridges, tunnels, rails, subways, airports, seaports, communications, water, power, and even major buildings, so it can better optimize its resources, plan its preventive maintenance activities, and monitor security aspects while maximizing services to its citizens.

Smart city initiatives try to improve urban performance by using data, information, and ICT to provide more efficient services to citizens, to monitor and optimize existing infrastructure, to increase collaboration among different economic actors, and to encourage innovative business models in both the private and public sectors.

A city performing well in a forward-looking way in the economy, people, governance, mobility, environment, and living, built on the smart combination of endowments and activities of self-decisive, independent, and aware citizens. A smart city generally refers to the search and identification of intelligent solutions which allow modern cities to enhance the quality of the services provided to citizens.

A city is smart when investments in human and social capital and traditional (transport) and modern (ICT) communication infrastructure fuel sustainable economic growth and a high quality of life, with a wise management of natural resources, through participatory governance.

Smart cities as territories with a high capacity for learning and innovation, which are built in the creativity of their population, their institutions of knowledge creation, and their digital infrastructure for communication and knowledge management.

A smart city infuses information into its physical infrastructure to improve convenience, facilitate mobility, add efficiencies, conserve energy, improve the quality of air and water, identify problems and fix them quickly, recover rapidly from disasters, collect data to make better decisions, deploy resources effectively, and share data to enable collaboration across entities and domains.

\section{Source}

(Washburn et al., 2010)

(Harrison et al., 2010)

(Hall, 2000)

(Marsal-

Llacuna et al., 2015)

(Giffinger et al., 2007) ${ }^{5}$

(Caragliu et al. 2011)

(Komninos, 2011)

(Nam \& Pardo, 2011) 
Continuation of Table 1

\section{Definition}

A smart city can make full use of information and communication technologies to sense, analyze, and integrate the information of the core system of city operation to make smart responses to various demands, including people's livelihoods, environmental protection, public safety, urban services, industrial and commercial activities, and to create a better urban life for mankind.

A smart city is based on the basic framework of a "digital city". It is connected with "real city" through ubiquitous sensor network, and automatically controls various facilities by a cloud computing platform, which can store, compute, and analyze massive data and assist in decision making.

The smart city is a reform and innovation system project carried out under the conditions of the modern information society, aiming at the practical needs of urban economic and social development, with the core aim of improving people's happiness and satisfaction to promote the wisdom of the urban development mode.

\section{Source}

(Smart city in

China, 2009)6

(Deren et al., 2014)

(Sisi et al., 2020)

education, culture, social welfare, public management, and economy (Neirotti et al., 2014). However, the simple combination of these dimensions cannot create a smart city. Instead, it should be regarded as an organic network or system, in which the relationships among urban sub-systems need to be considered.?

In summation, the definition of a smart city can be divided into three categories. The first type pays attention to the extensive and in-depth application of new generation ICT in cities. It points out that a smart city is one that integrates and improves urban operation systems through ICT. The second one attaches importance to the comprehensive development of the economy, society, culture, and environment based on ICT. The third one emphasizes the dynamic process of a smart city's development and regards it as an organic innovation process carried out by cities using ICT ${ }^{8}$ These $^{2}$ definitions seem to have a progressive evolutionary process. Information and communication technology is the important foundation for cities to realize "smart" development, while human wisdom is the soul of smart cities. The goal of smart cities is to realize the comprehensive sustainable development of the economy, society, and environment, which requires breaking through and transcending the traditional urban governance mode.

\section{Components of a Smart City}

The components of a smart city are in line with above-mentioned definitions. Scholars who define smart cities from a narrow perspective usually focus on the technical level and divide the idea of

6 China Information and Communication Research Institute (CICRI). (2019, November 13). Xīn zhihuì chéngshì de fāzhăn [Development of new smart cities]. https://mp.weixin.qq.com/s/h/3ZMn70gU11wuk5EjPavQ

Kanter, R. M., \& Litow, S. S. (2009). Informed and interconnected: A manifesto for smarter cities. (Working Paper No. 09-141). Harvard Business School. https://www.hbs.edu/faculty/Pages/item.aspx?num=36185

8 Xiaojuan, Z. (2015). Zhihui chéngshi xìtŏng de yāo sù, jiégòu jí móxing yánjiü [The elements, structure and model of smart city system] [Unpublished doctoral dissertation]. South China University of Technology. 
a smart city into its perception layer, network layer, and application layer. The so-called perception layer refers to the acquisition of basic data of the city based on the equipment for perceiving, measuring, capturing, and transferring information, such as radio frequency identification, infrared sensors, global positioning systems, laser scanners, mobile phones, etc. The network layer uses the internet, the Internet of Things, and information platforms to process, integrate, interact, and share scattered information, and explore the practical significance of city data by identifying problems of the city. The application layer is the most intuitive embodiment of a smart city's promotion of urban development. It provides corresponding data supports or decision-making services for the various functions and needs of the city. It is also a more differentiated level, including smart logistics, smart energy, smart transportation, smart tourism, smart medical care, smart environmental protection, etc. (Deren et al., 2014).

The conceptual framework of a smart city, in a broader sense, truly treats it as a city operation model. It does not only treat smart infrastructure, smart governance, and smart public services as derivative applications of technologies, but also considers them as basic parts of urban operation and integrates them into a more ambitious urban operation structure. Therefore, this elemental framework can be understood as the top-level design of a smart city and is the overall strategy guiding its development (Xibo \& Zaigao, 2010).

\section{The Practical Applications of Smart Cities in China}

\section{The Development History of Smart Cities}

Smart cities in China have developed over a decade, during which the government and enterprises have explored different ways to cooperate (Table 2). The whole process can be divided into three phases (Table 3).

The first phase took place from 2008 to 2012, which was the period in which the concept of a smart city was introduced. After the publication of "Smart Cities in China" by IBM in 2009, IBM began to cooperate with Chinese city governments, enterprises, and scholars to promote the construction of smart cities. Therefore, the early practice of smart cities in China was a commercial activity rather than a government initiative (Wang et al., 2013).

The second phase unfolded from 2012 to 2015, which was the pilot period of exploring the concept of a smart city. This was a period of promoting the smart city pilot projects, with pilot projects also being a common method in China for implementing policies. Due to a lack of coordination among various departments, there had been many different pilots in the smart city's construction, leading to a certain degree of confusion in the initial stage. Among these different pilots, those by the Ministry of Housing and Urban-Rural Development had the largest influential power; it has promoted 290 pilot cities in three batches. Since 2014, the construction of smart cities began to be standardized at the national level. The "Inter-Ministry Coordination Working Group for Promoting the Healthy Development of Smart City" was established, and the "Guiding Opinions on Promoting the Healthy Development of Smart Cities" were formulated to coordinate the work of various departments. At the same time, driven by emerging technologies such as $3 \mathrm{G}, 4 \mathrm{G}$, and cloud computing, pilot cities began to explore local cooperation in various business application fields. The construction of smart cities has gradually been brought on the right track (Sisi et al., 2020). 
Digital Law Journal. Vol. 2, No. 1, 2021, p. 29-47

Bo Qin, Su Qi / Digital Transformation of Urban Governance in China

\section{Table 2}

Smart City Pilot Projects in China

\begin{tabular}{|c|c|c|c|}
\hline Time & Department & Name of the pilot & Number \\
\hline 2010 & Ministry of Science and Technology & $\begin{array}{l}\text { Pilot cities of National } 863 \text { Smart } \\
\text { City Project }\end{array}$ & 2 \\
\hline 2012 & Chinese Academy of Engineering & "China Smart City" pilot city & 5 \\
\hline 2014 & $\begin{array}{l}\text { Ministry of Industry and Information } \\
\text { Technology }\end{array}$ & $\begin{array}{l}\text { Pilot and demonstration cities for } \\
\text { building a smart city }\end{array}$ & 2 \\
\hline 2013 & $\begin{array}{l}\text { National Administration of Sur- } \\
\text { veying, Mapping and Geographic } \\
\text { Information }\end{array}$ & $\begin{array}{l}\text { Pilot cities of smart city space-time } \\
\text { information cloud Platform }\end{array}$ & 10 \\
\hline 2013 & $\begin{array}{l}\text { Ministry of Housing and Urban-Rural } \\
\text { Development }\end{array}$ & $\begin{array}{l}\text { The first batch of national smart city } \\
\text { pilot cities }\end{array}$ & 90 \\
\hline 2013 & $\begin{array}{l}\text { Ministry of Industry and Information } \\
\text { Technolog, Ministry of Environmental } \\
\text { Protection, etc. }\end{array}$ & $\begin{array}{l}\text { Smart City Demonstration Pilot } \\
\text { Project }\end{array}$ & 6 \\
\hline 2013 & $\begin{array}{l}\text { Ministry of Housing and Urban-Rural } \\
\text { Development }\end{array}$ & $\begin{array}{l}\text { The second batch of national smart } \\
\text { city pilot cities }\end{array}$ & 103 \\
\hline 2013 & $\begin{array}{l}\text { Ministry of Industry and Information } \\
\text { Technology }\end{array}$ & $\begin{array}{l}\text { Pilot demonstration area of applica- } \\
\text { tion of public platform of e-govern- } \\
\text { ment based on cloud computing }\end{array}$ & 59 \\
\hline 2013 & $\begin{array}{l}\text { Ministry of Science and Technology, } \\
\text { National Standards Commission }\end{array}$ & $\begin{array}{l}\text { The National Smart City Pilot and } \\
\text { Demonstration City }\end{array}$ & 20 \\
\hline 2013 & $\begin{array}{l}\text { National Development and Reform } \\
\text { Commission, Ministry of Industry } \\
\text { and Information Technology }\end{array}$ & $\begin{array}{l}\text { Pilot cities for China-EU Smart City } \\
\text { Cooperation }\end{array}$ & 15 \\
\hline 2013 & $\begin{array}{l}\text { Ministry of Industry and Information } \\
\text { Technology }\end{array}$ & $\begin{array}{l}\text { National information consumption } \\
\text { pilot cities }\end{array}$ & 68 \\
\hline 2014 & $\begin{array}{l}\text { National Development and Reform } \\
\text { Commission }\end{array}$ & $\begin{array}{l}\text { Information benefit people national } \\
\text { pilot city }\end{array}$ & 80 \\
\hline 2015 & $\begin{array}{l}\text { Ministry of Housing and Urban-Rural } \\
\text { Development, Ministry of Science } \\
\text { and Technology }\end{array}$ & $\begin{array}{l}\text { The third batch of national smart } \\
\text { city pilot cities }\end{array}$ & 97 \\
\hline
\end{tabular}


Цифровое право. Том 2, № 1, 2021, с. 29-47

Б. Цинь, С. Ци / Цифровая трансформация городского управления в Китае

Table 3

Development History of Smart Cities in China

\begin{tabular}{|c|c|c|c|}
\hline & $\begin{array}{l}\text { Concept import } \\
(2008-2012)\end{array}$ & $\begin{array}{l}\text { Pilot exploration } \\
(2012-2015)\end{array}$ & $\begin{array}{l}\text { Coordinated advancement } \\
(2016-2020)\end{array}$ \\
\hline $\begin{array}{l}\text { Driving } \\
\text { mode }\end{array}$ & $\begin{array}{l}\text { Industry application } \\
\text { driven }\end{array}$ & $\begin{array}{l}\text { Emerging technology } \\
\text { driven }\end{array}$ & Data driven \\
\hline $\begin{array}{l}\text { Key } \\
\text { techno- } \\
\text { logy }\end{array}$ & $\begin{array}{l}\text { Wireless communication, } \\
\text { fiber optic broadband, } \\
\text { information distribution } \\
\text { technology such as HTTP, } \\
\text { GIS, GPS, RS }\end{array}$ & $\begin{array}{l}\text { RFID, } 2 \mathrm{G} / 3 \mathrm{G} / 4 \mathrm{G} \text {, Cloud } \\
\text { Computing, S OA }\end{array}$ & $\begin{array}{l}\text { 5G, Big data, artificial intelli- } \\
\text { gence, blockchain, Smart City } \\
\text { platform and OS }\end{array}$ \\
\hline $\begin{array}{l}\text { Infor- } \\
\text { mation } \\
\text { sharing }\end{array}$ & $\begin{array}{l}\text { Single system, scattered } \\
\text { construction, } \\
\text { spontaneous sharing }\end{array}$ & $\begin{array}{l}\text { Horizontal and vertical } \\
\text { division, share with key } \\
\text { projects or applications }\end{array}$ & $\begin{array}{l}\text { Horizontal and vertical system } \\
\text { integration, sharing according } \\
\text { to functions }\end{array}$ \\
\hline $\begin{array}{l}\text { Develop- } \\
\text { ment } \\
\text { charac- } \\
\text { teristics }\end{array}$ & $\begin{array}{l}\text { Enterprise introducing } \\
\text { concept, Foreign software } \\
\text { system integrators, IBM, } \\
\text { Oracle }\end{array}$ & $\begin{array}{l}\text { The ministries and } \\
\text { commissions of the } \\
\text { State take the lead } \\
\text { in carrying out pilot } \\
\text { construction, equip- } \\
\text { ment manufacturers, } \\
\text { integrators horse racing } \\
\text { enclosure }\end{array}$ & $\begin{array}{l}\text { National coordination, linkage } \\
\text { of } 25 \text { ministries and commis- } \\
\text { sions, government guidance, } \\
\text { market leadership, Public-Pri- } \\
\text { vate Partnership, domestic } \\
\text { internet enterprises, opera- } \\
\text { tors, software providers and } \\
\text { integrators all gather together }\end{array}$ \\
\hline
\end{tabular}

The third phase was launched in 2016. The development concept, construction idea, implementation path, operation mode, and technical means of a smart city have all been upgraded. ${ }^{9}$ The concept of a smart city has been regarded as a national strategy for new urbanization and industrial transformation. A series of supporting policies and plans have been introduced which has formed the government-guided and market-led pattern. Some new commercial activities and smart services are emerging, making up a ubiquitous idea of smart living.

\section{Contents of Smart City Practices}

Until now, the content of China's smart city policy has been comprehensive. In addition to infrastructure, application platforms, smart economy, smart governance, and smart ecology, policy and standards, top-level design, and related security measures are also involved.

\section{Policy and Standards}

Since the promulgation of the "Interim Management Measures for National Smart City Pilots" in 2012, China has issued a series of policies, technology standards, and evaluation standards for smart cities at the national and provincial levels (Table 4). These policies and standards can provide guidance for the development of smart cities at various stages.

9 CICRI, 2019. 
Digital Law Journal. Vol. 2, No. 1, 2021, p. 29-47

Bo Qin, Su Qi / Digital Transformation of Urban Governance in China

\section{Table 4}

Relevant Policy and Standards for Smart City in China

\begin{tabular}{|c|c|c|}
\hline $\begin{array}{l}\text { Release } \\
\text { time }\end{array}$ & Name of policy or standard & Related content \\
\hline 2012 & $\begin{array}{l}\text { Interim Administrative Measures for } \\
\text { National Smart City Pilot Project }\end{array}$ & $\begin{array}{l}\text { Guiding the application, implementation, } \\
\text { and management of national smart city pilot } \\
\text { projects }\end{array}$ \\
\hline 2012 & $\begin{array}{l}\text { National Smart City (District, Town) } \\
\text { Pilot Indicator System (Trial) }\end{array}$ & $\begin{array}{l}\text { Making clear the indicator system of the } \\
\text { smart city pilot }\end{array}$ \\
\hline 2013 & $\begin{array}{l}\text { Several Opinions on Promoting } \\
\text { Information Consumption and } \\
\text { Expanding Domestic Demand }\end{array}$ & Accelerating the development of smart cities \\
\hline 2014 & $\begin{array}{l}\text { Notice on Accelerating the Imple- } \\
\text { mentation of the Information Project } \\
\text { for the Benefit of the People }\end{array}$ & $\begin{array}{l}\text { Promoting the work of smart cities from the } \\
\text { perspective of improving the quality of life } \\
\text { with ICT }\end{array}$ \\
\hline 2014 & $\begin{array}{l}\text { National New Urbanization Plan } \\
(2014-2020)\end{array}$ & $\begin{array}{l}\text { Putting forward the key points and requirements } \\
\text { promoting the construction of a smart city }\end{array}$ \\
\hline 2014 & $\begin{array}{l}\text { Guidelines on Promoting the Healthy } \\
\text { Development of Smart Cities }\end{array}$ & $\begin{array}{l}\text { Putting forward the development idea, con- } \\
\text { struction principle, main goal, and informa- } \\
\text { tion security guarantee of China's smart city }\end{array}$ \\
\hline 2015 & $\begin{array}{l}\text { Guidance on the Construction, Appli- } \\
\text { cation, and Implementation of Smart } \\
\text { City Standard System and Evaluation } \\
\text { Index System }\end{array}$ & $\begin{array}{l}\text { Accelerating the formulation of relevant } \\
\text { standards, and putting the standardization } \\
\text { of smart cities on the national agenda }\end{array}$ \\
\hline 2016 & $\begin{array}{l}\text { Task Division of Inter-Ministerial } \\
\text { Coordination Working Group on New } \\
\text { Smart City Construction (2016-2018) }\end{array}$ & $\begin{array}{l}\text { Clarifying the tasks and responsibilities of } \\
\text { the } 25 \text { member departments of the In- } \\
\text { ter-ministerial Coordination Working Group }\end{array}$ \\
\hline 2016 & $\begin{array}{l}\text { Evaluation Index of New Smart City } \\
\text { (2016) }\end{array}$ & $\begin{array}{l}\text { Making clear the evaluation index of a smart } \\
\text { city }\end{array}$ \\
\hline 2017 & $\begin{array}{l}\text { Technical Outline for the Construc- } \\
\text { tion of Smart City Space-time Big } \\
\text { Data Platform (2017 Edition) }\end{array}$ & $\begin{array}{l}\text { Realizing the promotion of smart city's } \\
\text { space-time benchmark, space-time big data, } \\
\text { and space-time information cloud platform }\end{array}$ \\
\hline 2018 & $\begin{array}{l}\text { Evaluation Index of New Smart Cities } \\
\text { (2018) }\end{array}$ & Updating the evaluation index of smart cities \\
\hline 2019 & $\begin{array}{l}\text { Technical Outline for the Construc- } \\
\text { tion of Smart City Space-time Big } \\
\text { Data Platform (2019 Edition) }\end{array}$ & $\begin{array}{l}\text { Further developing the space and time big } \\
\text { data platform for smart cities }\end{array}$ \\
\hline
\end{tabular}




\section{Top-Level Design}

The continuous expansion of smart cities has resulted in a constant increase in the complexity of this systematic project. Strengthening the top-level design of smart cities is the primary step to make this work efficiently and orderly. In January 2019, China formally implemented the "Guidelines for Top-Level Design of Smart Cities", so that top-level design and overall planning have become a prerequisite for the implementation of smart cities. The proportions of national-level urban agglomerations, national-level new districts, provincial capital cities and cities separately listed in the state plan, prefecture-level cities, and county-level cities in developing smart cities' top-level designs or overall plans are $23 \%, 52 \%, 94 \%, 71 \%$, and $25 \%$ respectively.

\section{Infrastructure}

Chinese cities have different key points when promoting smart cities, but ICT is always the foundation of such cities. Earlier infrastructure construction, which was based on broadband, 3G, and $4 \mathrm{G}$, has shifted to new infrastructure, instead incorporating $5 \mathrm{G}$, the Internet of Things, and cloud computing. Beijing, Shanghai, Guangzhou, Shenzhen, Chongqing, Chengdu, Hangzhou, and Shenzhen have almost achieved $5 \mathrm{G}$ coverage as of now. Regarding the Internet of Things, five new industrial demonstration bases have been established at the national level, such as Wuxi and Hangzhou.

\section{Application Platform}

With the continuous accumulation of urban data, as well as the in-depth application of various technologies such as big data, artificial intelligence, and blockchain, the integration of key common capabilities will be strengthened to eliminate the problem of data islands. The urban big data platform, which originated from the early days of the sharing exchange platform regarding government affairs, has gradually expanded to other fields. It has incorporated various data such as urban operation perception data, enterprise data, and internet data, which has made it the core component platform of a smart city. With the mature application of new surveying and mapping, analog simulation, deep learning, and other technologies, the construction of one-to-one mapping digital twin cities in the digital space is becoming a new exploration in Xiong'an and Chongqing.

\section{Smart Living}

The construction of a "smart city" has fully entered a new stage with service at the core. Smart government services have been popularized, and services that benefit the people and enterprises within reach have in recent years become the development focus of a smart city. With the in-depth advancement of "internet + government service", the convenience of online administration of government services has been continuously improved. Online inquiries and the online handling of public services have basically been popularized nationwide. Some areas have adopted government big data, government service robots, and other intelligent means to promote government affairs, data standardization, service networking, and processing automation. For example, "appropriation with the application" in Shanghai and "Guangdong Provincial Affairs" in Guangdong Province can help citizens to obtain one-stop services such as government services, payment, e-commerce, travel, and meal ordering, realizing multiple channels and a wide coverage of services. These kinds of apps are becoming the new infrastructure pertaining to public services.

$10 \quad$ CICRI, 2019. 


\section{Smart Economy}

At present, 23 provincial-level regions in China have introduced top-level designs in the digital economy. With the core concept of "industry-city integration", the construction of smart cities will help in promoting two-way data circulation between governments and enterprises, cultivating several leading digital service companies, and exploring a win-win pattern for urban transformation and industrial innovation. Overall, China's digital industry is still led by the four major clusters of the Beijing-Tianjin-Hebei, Yangtze River Delta, Pearl River Delta, and Chengdu-Chongqing urban agglomerations.

\section{Smart Governance}

The development and innovative applications of the new generation of ICT have greatly improved social governance capabilities and promoted smart city governance methods that are more digital, networked, and intelligent. "Internet + supervision" has gradually developed into an effective means of strengthening in-process and post-event supervision. Many cities make full use of big data and social credit systems to strengthen the tracking and early warning of market risks. For example, Beijing relies on the Enterprise Credit Information Network to list 200000 enterprises in the list of business abnormalities, and uses big data technology to effectively control market supervision risks and to implement cross-department joint credit punishments on untrustworthy enterprises. In the field of urban security, Baidu is building an intelligent video surveillance platform for a smart city and smart security, providing full-process services including camera equipment management, video stream access, video frame extraction, video analysis, and alarm information display. The platform has the ability of surveilling helmet wearing compliance testing, work clothes compliance testing, fireworks testing, stranger recognition, smoking recognition, and mobile phone recognition.

\section{Smart Ecology}

The concept of green sustainable development is an important component of smart cities. Driven by technological innovation and the demand for sustainable development, many cities are actively exploring greener and lower-carbon production and lifestyles and promoting more precise ecological monitoring. The $5 \mathrm{G}$ integrated ecological detection system built by Xiong'an New Area utilizes the high speed and low latency of $5 \mathrm{G}$, as well as the all-weather and all-terrain inspection features of drones and unmanned ships, to realize the ecological conditions and water quality monitoring of Baiyangdian. Its data are instantly uploaded to the platform for analysis, and it supports the staff to observe the analysis results and on-site conditions through monitoring screens and virtual reality (VR) glasses.

\section{Data Security}

While the development of smart cities brings more convenient services to the public, the increased complexity of network platforms also simultaneously brings about the problem of digital space security. "Personal privacy protection" and "autonomy and trustworthiness" have become the focus of attention. The national level continues to increase the high-pressure supervision of data collection in violation of mobile application services. The Central Cyberspace Affairs Office is cooperating with the other four ministries to set up the "Special Task Force on App collection and use of personal information in violation of laws and regulations". The Special Task Force aims to evaluate mobile applications in key areas, sort out the "blacklist" of illegal applications, and carry out supervision and rectification work. 


\section{Operation Models of a Smart City}

Smart cities involve not only the evolution of the established concepts and the construction of infrastructure, but also the models of investment, operation management, and profit need, in order to enable the sustainable development of smart cities and to allow more people to benefit from them. In the process of developing a smart city, local governments have explored and developed some models to clarify the roles of government and enterprises.

\section{Institutional Setting}

The construction of smart cities is a systematic project involving a wide range of areas. Overall, specialized smart city management agencies in China are divided into two categories. The first one is the newly established Big Data Bureau, or other such specialized agencies which manage the construction of a smart city. At present, many cities have set up big data authorities with data resource management as the core function and are becoming the main institutions for data integration and sharing. According to our survey data, 277 cities across the country have established Big Data Bureaus or similar specialized agencies. The second one is the responsibility assumed by the Ministry of Industry and Informatization, the Development and Reform Commission, and the Cyberspace Administration of China. Tianjin, Hebei, Liaoning, Shanghai, Jiangsu, Zhejiang, and some other provinces have assumed responsibility.

\section{Investment Models}

Developing smart cities requires high levels of infrastructure and technological innovation, and a large amount of capital investment. From the perspective of operating funds, Wang et al. (2013) summarized the investment of smart cities into three models. First, the government independently invests in network construction and is responsible for maintenance. This model is mostly used in government affairs and some public service fields in which the main purpose is not to make profit. Second, the government takes the lead and is responsible for major investments, while the commissions operators provide relevant support and obtain some particular benefits or subsidies. This type of model gives the government higher regulatory capabilities, but the operators have little influence on product planning and layout. Third, the government provides limited infrastructure and policy support, and operators are responsible for the main investment, construction, and operation (Wang et al., 2013). In the initial stage of the construction of smart cities in China, local telecom operators were the mainstay, and then the local government was gradually encouraged to cooperate with social capital. Some technology companies and social capital, such as Alibaba and Huawei, began participating. The construction of smart cities has evolved from a single government-led model to a diversified model of social participation and joint construction and operation.

\section{Operation Models}

At present, among the 657 cities that carried out data monitoring, 433 (accounting for $65.91 \%$ ) have developed smart city projects with non-governmental agencies (firms and NGOs) acting as the main body. With the upgrading of a smart city, new operating models and the relationship between government and enterprises have emerged, giving rise to the role of "smart city operators" to coordinate the construction, operation, and management of smart cities.

Smart city operators can be divided into two categories. The first is where the government and enterprises cooperate to establish specialized operating companies. This model could be described as "government-enterprise cooperation, the separation of management and operation", which is the 
innovation of Guangdong's "digital government" reform. The government departments took greater management responsibilities for analyzing needs and evaluating services. Tencent, China Mobile, China Unicom, and China Telecom jointly funded the Digital Guangdong Network Construction Co. Ltd., which assumed the operating responsibilities, including a series of tasks such as standard formulation, demand docking, data fusion, and system operation. The other category is to carry out the smart city initiatives that rely on large companies. In Zhejiang, Alibaba has proposed its being an in-depth partner not only for business cooperation but also for all aspects of planning, design, construction, and services.

\section{Profit Models}

The construction and maintenance of smart cities require a large amount of capital investment, which is financially difficult for the government to bear. Therefore, the development of smart cities must form a clear profit model to ensure sustainability.

At present, the profit model of smart city projects is mainly divided into three categories. The first is to accumulate users and monetize network flow. This entails accumulating many users through smart tourism, smart education, and other projects, and then providing value-added services to monetize network flow. For example, Tencent cooperated with the Puzhehei government in Yunnan Province to build a smart scenic spot, relying on a large amount of tourist information to develop "tourism installment", "tourism loan", and other business schemes.

The second is based on contract management and revenue sharing. For example, for a smart streetlight project invested by a company, the government will repay the saved electricity bills to the company in installments. When the contract management expires, the smart streetlight will be transferred to the government free of charge. This zero-government investment model effectively solves the problem of lack of funds and realizes the "three-win" situation of government saving money, social energy saving, and corporate profits.

The third is data desensitization and limited operation. The desensitized data is leased to an enterprise for further exploration of their potential commercial value. For example, in an Urban Smart Campus Project, the campus monitoring, campus surrounding monitoring, and school bus monitoring are integrated and opened to professional operating companies through the integrated urban operation platform. The operating companies can provide paid services to the government, schools, and parents, whilst allows parents to track their children's activity through the application.

\section{The Challenge Facing the Adoption of a "Smart City" Model}

Smart cities are the product of technology and an urban development; in a short period, this has hugely influenced and nurtured many emerging businesses in China. Such rapid development will inevitably impact the original social legal order and pose unforeseen danger for the development of cities. Poor laws and regulations, similar / uniform / monotonous conceptions of smart cities, and isolated information islands are some of the challenges that should be resolved in future.

\section{Legal Challenges}

The development of smart cities depends on the advancement of related technologies such as the Internet of Things, big data, and artificial intelligence. This has created a double-layered space between the networked society and the real society, which is characterized by the coexistence of 
humans and machines (Changshan, 2018). This new social organization has profoundly changed legal values, legal relations, and legal practices.

In terms of legal practice, the current smart city construction mainly involves two legal issues: one for "people", the other for "things". Specifically, it includes the issue of the civil subject of the legal qualification of robots (Yujie, 2017), the copyright issue of works generated by artificial intelligence (Zhiwen, 2017), the tort law issue of human damage caused by intelligent systems (Handong, 2017), the personal rights issue of human data privacy protection (Wei, 2016), the traffic law issues of intelligent driving systems (Xiao \& Jianfeng, 2017), the labor law issues of machine "workers" (Handong, 2017), and so on. These emerging issues have posed a huge challenge for China's existing legal system.

Firstly, existing legal norms are difficult to adjust and ineffectively cover legal interests. The development of smart interconnection has spawned many emerging things and businesses, such as smart contracts, virtual currencies, online shopping, ride-hailing, etc. These have formed an unprecedented relationship and fashioned a new framework of rights and obligations; for existing legal concepts, rules, and principles, this is difficult to effectively cover. Secondly, it is becoming increasingly difficult for this to be explained effectively by China's existing civil and commercial laws, theories, and rules. In the context of a smart city, data resources have become important factors of production and social wealth. A series of platform companies, such as Tencent, Taobao, and JD, are constantly excavating and analyzing data to realize their own business interests. However, the nature, classification, ownership, usage rules, and legal responsibilities of data and information lacks explanatory power in this regard.

In addition, various platforms, based on their business type and operational needs, have the right to self-regulate the marketing order of the platform themselves. The government has no time or ability to supervise the huge, ever-changing, and technical platform transactions. Instead, review management power has been granted to platforms in the form of laws, regulations, or rules. They have the rights to formulate platform rules, penalize platform violations, and resolve platform disputes, which are the powers of quasi-legislation, quasi-enforcement, and quasi-judicial. This undoubtedly affects government intervention and market self-discipline, and the concepts, principles, and regulatory methods of administrative law have also encountered challenges (Changshan, 2018).

Finally, the existing judicial dispute resolution mechanism has also encountered obvious obstacles. The intelligent, hierarchical, and fragmented characteristics of internet crime make it difficult to adapt to the crime detection system based on traditional geographical and hierarchical jurisdiction. The detection rate of crimes such as cyber fraud is low, but the cost is high. Although China has established an internet court in Hangzhou, it lacks a clear legal system and clear responsibilities. There are still many issues that need to be resolved for the court in terms of jurisdiction, trial procedures, case trials, and judgment enforcement.

Taking the China National Health Code as an example, the promotion of the health code has become a pioneering work in China's epidemic prevention and control; however, it also runs personal information security risks. On the one hand, a large amount of sensitive personal information is concentrated under government control with the risk of personal information leakage; on the other hand, the handling of personal information lacks legal guidelines, and there are a large number of personal information processing activities that ignore the principle of informed consent and exceed the principle of minimum use and disclosure (Yuan, 2020).

In the field of data security, Europe and the United States have already conducted some legal explorations. The United States has passed the Consumer Privacy Bill of Rights Act of 2015 (CPBR), introduced a new scenario-led personal information protection mechanism, and taken the lead in 
breaking through the current global structural model. The EU has added new mechanisms such as data breach notification, privacy impact assessment, and third-party certification in its draft "General Data Protection Regulation" (GDPR), highlighting new concepts such as scenario orientation and risk assessment (Wei, 2016).

China implemented the Cyber Security Law in 2017, but it is not maneuverable enough, with less than a half of normative clauses (Qin, 2020). China still lacks clear legislation aiming at data privacy and security, and relevant regulations mainly rely on regulatory documents of government departments. At the national level, China has enacted "Guiding Opinions on Promoting the Healthy Development of Smart City". At the same time, Shenzhen, Shanghai, Yinchuan, Tianjin, and other cities have also issued relevant documents on information security, which put forward requirements for data security management; nevertheless, their legal validity and enforcement binding have some limitations. At present, the relevant laws, regulations, systems, and policies in the field of smart cities need further improvements to promote their safe, healthy, and orderly development.

\section{Commercial Challenges}

Although the concept of a smart city has become the development model chosen by many, it is prudent to highlight some of the criticisms raised against this concept. The definition of a smart city has always been relatively vague, often associated with an intelligent, creative, and digital city. It regularly implies a relationship between technological progress and political, economic, and cultural changes. The hype of these terms is difficult to separate from the real practice, and eventually they are used more for the purpose of city marketing wherein some emerging cities are advertised as "smart cities" (Hollands, 2008).

These cities pay more attention to business-led urban development, hoping to use network infrastructure to improve economic and political efficiency and promote social, cultural, and urban development. However, their focus is on specific high-tech and creative industries. Hollands believes that a smart city has a technological determinism and capital dependence tendency to some degree but pays insufficient attention to people; at the same time, he also questioned the environmental sustainability of a smart city (2008). An important question is whether a smart city is truly environmentally friendly; the ICT revolution may not be as environmentally friendly as it initially seemed (Hollands, 2008). Even in some cities that truly practice the principles of a "smart city", they have introduced specific technical parameters to distinguish between "good" and "bad" cities, leaving a new moral order for cities. Therefore, the discourse of a smart city may be a powerful tool for generating docile subjects and political legitimization mechanisms (Vanolo, 2013).

The construction of smart cities in China initially had obvious commercial tendencies. After a period of governmental guidance, companies still play a pivotal role. This confirms Hollands' criticism of a smart city's commercial orientation. The result is that many cities rushed into mass action. China carried out "smart city" construction in more than 320 cities in 2012. The local governments followed the experience of urban construction and formed path dependence, which restricts the innovation and development of cities. The practices and functions of every smart city are very similar, so effective complementary relationships cannot be formed between cities (Shengzu et al., 2013). Due to the lack of a reasonable top-level design, blindly following the trend has also led to the inadequate understanding of a "smart city" in some cities. They either only emphasize the informatization projects, or include all kinds of irrelevant tasks into the scope of a smart city (Biyu et al., 2015). Besides, the technological orientation and capital-dependency of smart cities have formed a spatial aggregation 
and imbalance. There is a clear gap in the construction level between the east and the west, and between cities of different levels (Liying \& Chao, 2019).

\section{Information Fragmentation Challenges}

As IBM said, a smart city can make full use of ICT to sense, analyze, and integrate various information in the core system of city operation." After more than ten years of development, China's current smart city projects still face information islands as the biggest obstacle to resource integration.

At the technical level, the notion of a smart city covers many areas but currently lacks uniform guiding standards in terms of construction, operation, and evaluation. The interfaces between different systems are complicated, which makes it difficult to achieve system interconnection, information sharing, and coordination. At the practical level, although various departments in the city have accumulated massive amounts of data and information in the long-term informatization application, the independence and segmentation of each system and the lack of scientific and effective information sharing mechanisms have led to many informatization islands. At the management level, it is difficult for urban departments to coordinate horizontally; administrative and managerial divisions are widespread. Some collaborative problems are often technically easy to solve but practically difficult to address within the management systems (Shengzu et al., 2013).

\section{Conclusion}

As a solution to urban problems, particularly after the 2008 economic crisis, the notion of a smart city has opened new development paths for cities. Relying on the sudden emergence of $5 \mathrm{G}$, cloud computing, the Internet of Things, and other technical fields, China has made relatively outstanding progress in the construction of smart cities. China has built up mature basic technical facilities and application platforms, and related technologies are widely used in the fields of economy, governance, and general life. At the same time, results evaluation and sustainable models are also constantly being explored. These achievements have brought groundbreaking changes to China's urban development in the past decade. However, apart from such achievements, there are still barriers such as "information islands" in construction, technology, and management. These tremendous changes have also led to the criticisms of "labeling" and "urban marketing" being levelled at a part of so-called smart cities, which has brought new challenges to China's economic, legal, and social orders.

In the future, China needs to further improve laws and regulations, build an integrated legal system, explore new regulation methods, shape a highly autonomous and refined governance order, promote effective law enforcement, justice, embed risk control institutional mechanisms, maintain a good legal order, and provide legal protection for the development of smart cities. At the same time, the supervision of smart cities should be strengthened through reasonable evaluation to weaken the marketing motivation of some cities using the "smart city" model as a gimmick. In addition, further research in the fields of technology and management is needed to eliminate "information islands" and find a "smart city" development path that can realize resource integration and sharing.

$11 \quad$ CICRI, 2019. 


\section{References:}

1. Alawadhi, S., Aldama-Nalda, A., Chourabi, H., Gil-Garcia, J. R., Leung, S., Mellouli, S., Nam T., Pardo, T. A., Scholl H. J., \& Walker, S. (2012). Building understanding of smart city initiatives. In Scholl H.J., Janssen M., Wimmer M.A., Moe C.E., \& Flak L.S. (Eds.), Lecture notes in computer science: Vol. 7443 LNCS. Electronic government (pp. 40-53). Springer. https://doi.org/10.1007/978-3-642-33489-4_4

2. Biyu, W., Junlan, L., Weiru, Z., Dong, J., \& Guoqiang, Z. (2015). Analysis on practice of smart city pilot. Modern Urban Research, 1, 2-6. https://doi.org/10.3969/j.issn.1009-6000.2015.01.001

3. Caragliu, A., Del Bo, C., \& Nijkamp, P. (2011). Smart cities in Europe. Journal of Urban Technology, 18(2), 65-82. https://doi.org/10.1080/10630732.2011.601117

4. Changshan, M. (2018). Legal changes in the era of the intelligent Internet. Chinese Journal of Law, 40(4), 20-38. http://www.faxueyanjiu.com/Magazine/Show?ID=69344

5. Deren, L., Yuan, Y., \& Zhenfeng, S. (2014). Big data in smart city. Geomatics and Information Science of Wuhan University, 39(6), 631-640. https://www.cnki.net/kcms/doi/10.13203/j.whugis20140135.html

6. Wang, G. B., Lei, Z., \& Honglei, L. (2013). Guo nei wai zhi hui cheng shi li lun yan jiu yu shi jian si kao [Theoretical research and practical consideration of smart city in China and abroad]. Science \& Technology Progress and Policy, 30(19), 153-160. http://caod.oriprobe.com/articles/40698520/guo_nei_wai_zhi_hui_cheng_shi_ li_lun_yan_jiu_yu_shi_jian_si_kao_htm

7. Handong, W. (2017). Réngōng zhìnéng shídài de zhìdù ānpái yǔ fălü guīzhì [Institutional arrangement and legal regulation in the era of artificial intelligence]. Oriental Law, 5, 98. http://www.iolaw.org.cn/showNews. aspx?id=61404

8. Harrison, C., Eckman, B., Hamilton, R., Hartswick, P., Kalagnanam, J., Paraszczak, J., \& Williams, P. (2010). Foundations for smarter cities. IBM Journal of Research and Development, 54(4), 1-16. https://doi.org/10.1147/ JRD.2010.2048257

9. Hollands, R. G. (2008). Will the real smart city please stand up? City, 12(3), 303-320. https://doi.org/10.1080/ 13604810802479126

10. Komninos, N. (2011). Intelligent cities: Variable geometries of spatial intelligence. Intelligent Buildings International, 3(3), 172-188. https://doi.org/10.1080/17508975.2011.579339

11. Liying, Y., \& Chao, Z. (2019). Zhōngguó zhìuì chéngshì lǐlùn yánjiū zòngshù yǔ shijiàn jìnzhăn [A review of the theoretical research and practical progress of smart city in China]. E-Government, 1, 111-121. http://www.cnki.com.cn/Article/CJFDTotal-DZZW201901018.htm

12. Washburn, D., Sindhu, U., Balaouras, S., Dines, R. A., Hayes, N. M., \& Nelson, L. E. (2010). Helping CIOs understanding smart city initiatives: Defining the smart city, its drivers, and the role of the ClO. Cambridge.

13. Marsal-Llacuna, M.-L., Colomer-Llinàs, J., \& Meléndez-Frigola, J. (2015). Lessons in urban monitoring taken from sustainable and livable cities to better address the Smart Cities Initiative. Technological Forecasting and Social Change, 90(B), 611-622. https://doi.org/10.1016/j.techfore.2014.01.012

14. Nam, T., \& Pardo, T. A. (2011). Conceptualizing smart city with dimensions of technology, people, and institutions. Proceedings of the 12th Annual International Conference on Digital Government Research Conference: Digital Government Innovation in Challenging Times, 282-291. https://doi.org/10.1145/2037556.2037602

15. Neirotti, P., De Marco, A., Cagliano, A. C., Mangano, G., \& Scorrano, F. (2014). Current trends in smart city initiatives: Some stylized facts. Cities, 38, 25-36. https://doi.org/10.1016/j.cities.2013.12.010

16. Qin, Z. (2020). Zhìhuì chéngshì zhilĭ zhōng gèrén xìnxī de quányì jiěxī hé quánlì băohù [Rights and interests analysis and protection of personal information in the management of smart cities]. Social Sciences in Nanjing, 11, 93-97. https://kns.cnki.net/kcms/detail/detail.aspx?doi=10.15937/j.cnki.issn1001-8263.2020.11.013 
17. Shengzu, G., Jianwu, Y., \& Jiangri, L. (2013). Dāngqián wǒguó zhihuì chéngshì jiànshè zhōng de wèntí yǔ duìcè [Problems in the development of smart city in China and their solution]. China Soft Science Journal, 1, 6-12. https://doi.org/10.3969/j.issn.1002-9753.2013.01.002

18. Shengzu, G., \& Min, W. (2012). Theoretical considerations and strategic choice on the development of smart city. China Population, Resources and Environment, 22(5), 74-80. https://doi.org10.3969j.issn10022104.2012.05.013

19. Sisi, T., Yanqiang, Z., Zhiguang, S., Wei, W., \& Yaqi, Z. (2020). Wǒguó xīnxíng zhìhuì chéngshì fãzhăn xiànzhuàng, xíngshì yŭ zhèngcè jiànyì [Development status, situation and policy suggestions of China's new smart cities]. E-Government, 4, 70-80. https://doi.org/10.16582/j.cnki.dzzw.2020.04.007

20. Vanolo, A. (2013). Smartmentality: The smart city as disciplinary strategy. Urban Studies, 51(5), 883-898. https://doi.org/10.1177\%2F0042098013494427

21. Wei, F. (2016). Reconstruction of the path of personal information protection in the era of big data. Global Law Review, 38(5), 92-115. https://doi.org/10.3969/j.issn.1009-6728.2016.05.007

22. Xiao, S., \& Jianfeng, C. (2017). Lùn réngōng zhìnéng de mínshì zérèn: Yǐ zìdòng jiàshĩ qìchē hé zhìnéng jīqiirén wéi qiērù diăn [Civil liability of artificial intelligence: A perspective on autonomous vehicles and intelligent robots]. Science of Law, 35. https://www.ixueshu.com/h5/document/e9d0c5b740fa830675b85bc07c8b6901318947a18e7f9386.html

23. Xibo, W., \& Zaigao, Y. (2010). Zhìhuì chéngshì lǐniàn yǔ wèilái chéngshì fāzhăn [The concept of smart city and future city development]. Urban Studies, 17(11), 56-60. https://doi.org/10.3969/j.issn.1006-3862.2010.11.009

24. Yuan, N. (2020). Jiànkāng mă yùnyòng zhōng de gèrén xìnxī băohù guīzhì [Regulation of personal information protection in health code application]. Law Review, 38(6), 111-121. https://doi.org/10.13415/j.cnki. fxpl.2020.06.012

25. Yujie, Z. (2017). Lùn réngōng zhìnéng shídài de jīìirén quánlì jỉ qí fēngxiăn guīzhì [Robot rights and risk regulation in the age of artificial intelligence]. Oriental Law, 6, 56-66. http://iolaw.org.cn/showNews. aspx?id=62222

26. Zhiwen, L. (2017). Réngōng zhìnéng chuàngzuò wù de zhùzuòquán băohù wèntí yánjiū [Legal protection of artificial intelligence creations]. Science of Law, 35(5), 156-165. http://gb.oversea.cnki.net/KCMS/detail/detailall.aspx?filename=1018874939.nh\&dbcode=CMFD\&dbname=CMFDREF

\section{Information about the authors:}

Bo Qin* - Ph.D., Professor, Head of the Department of Urban Planning and Management, Renmin University of China, Beijing, People's Republic of China.

qinbo@vip.sina.com

Su Qi - Master student, Department of Urban Planning and Management, Renmin University of China, Beijing, People's Republic of China.

Сведения 06 авторах:

Цинь Б.* - Ph.D., профессор, заведующий кафедрой городского планирования и управления Университета Жэньминь, Пекин, Китайская Народная Республика.

qinbo@vip.sina.com

Ци С. - студент магистратуры кафедры городского планирования и управления Университета Жэньминь, Пекин, Китайская Народная Республика. 